\title{
Seasonal variations of mixotrophic ciliates in the northwest Mediterranean Sea*
}

\author{
Catherine Bernard**, Fereidoun Rassoulzadegan \\ URA-CNRS 716, Station Zoologique, BP 28, F-06230 Villefranche-sur-Mer, France
}

\begin{abstract}
The seasonal distribution of mixotrophic oligotrichous ciliates was compared to that of the strict heterotrophic oligotrichs and of the autotrophic haptorid Mesodinium rubrum, in surface coastal waters of the Ligurian Sea, from March 1988 to December 1989. The results show that (1) mixotrophic ciliates, which were observed year-round, average $51 \%$ of the overall biovolume (from $45 \%$ for cells 30 to $50 \mu \mathrm{m}$ to $57 \%$ for cells $>50 \mu \mathrm{m})_{i}(2)$ mixotrophs dominate the ciliate populations in spring and in summer (average $>60 \%$, maximum $100 \%$ ); (3) pigmented ciliates, mixotrophic oligotrichs and $M$. rubrum dominate the biovolume of ciliates in the size ranges $<30$ and $>50 \mu m_{i}(4)$ besides numerous Strombidium spp., 5 mixotrophic species belonging to the genera Tontonia, Laboea and Lohmaniella were observed; and (5) a positive correlation was found between biovolume of pigmented ciliates and light and between biovolume of mixotrophic clliates and biovolume of cyanobacteria.
\end{abstract}

KEY WORDS: Mxotrophy - Oligotrichs - Mesodinium rubrum - Seasonal distribution NW Mediterranean

\section{INTRODUCTION}

Mixotrophy is a nutritional pathway which combines heterotrophy and autotrophy (Laval-Peuto et al. 1986, Jonsson 1987, Stoecker 1987), either simultaneously or alternately (amphitrophy - see review by Laval-Peuto 1992). Mixotrophy is known in several protistan phyla (Sanders 1991, Dolan 1992, Laval-Peuto 1992). In the Strombididae (Oligotrichida), mixotrophy is due either to plastid retention (Stoecker et al. 1987, Laval-Peuto 1992), or to purple non-sulphur bacteria symbiosis known in only Strombidium purpureum (Fenchel \& Bernard 1993a, b).

Earlier studies of mixotrophic oligotrichs which harbour plastids focused on photosynthesis and respiration (McManus \& Fuhrman 1986, Jonsson 1987. Putt 1990a. Stoecker \& Michaels 1991) or on ultrastructural features (Laval-Peuto et al. 1986). These studies showed that products of photosynthesis are available

- Contribution of the URA 716 'Ecologie du Microzooplancton marin

- Present address: Marine Biological Laboratory, University of Copenhagen, Strandpromenaden 5. DK-3000 Helsingor, Denmark to the ciliates and could provide them with an advantage in heterogeneous and patchy environments such as oligotrophic ones (Laval-Peuto 1992). Mixotrophic oligotrichs have been recorded both in freshwater (Rogerson et al. 1989) and in seawater such as the Mediterranean Sea, the Atlantic Ocean, the Baltic proper, the Kattegat/Skagerrak, Norwegian fjords, the Antarctic and the Arctic (McManus \& Fuhrman 1986. Jonsson 1987, Laval-Peuto \& Rassoulzadegan 1988, Stoecker el al. 1989, Auf dem Venne 1990, Nielsen et al. 1990, Putt 1990b, Stoecker et al. 1992, Verity \& Vernet 1992). Available data on the distribution of mixotrophic ciliates, except for an annual survey in the waters of Great Harbor, USA (Stoecker et al. 1987), deal with short periods. During their survey, Stoecker et al. (1987) found that the biomass of mixotrophic ciliates might range from 18 to $81 \%$ of the ciliate fauna.

The seasonal distribution of mixotrophic planktonic oligotrichs in the Mediterranean Sea was investigated over 21 mo with the aim of surveying their occurrence in aligo- to mesotrophic water. The seasonal distribution patterns were compared to those of strict heterotrophic oligotrichs and of the autotrophic Haptorida Mesodinium rubrum and also to parameters such as light intensity and autotrophic pico-and nanoplankton. 


\section{MATERIAL AND METHODS}

Surface seawater samples were collected (average of 2 times a week) with an acid-rinsed carboy at Point B, a standard oceanographic station at the mouth of the Bay of Villefranche, NW Mediterranean (43 $41^{\prime} 10^{\prime \prime} \mathrm{N}$, $7^{\circ} 19^{\prime} 0^{\prime \prime}$ E) during the period March 1988 to December 1989. Samples were transported directly to the laboratory within $1 \mathrm{~h}$ after sampling.

Prior to plankton concentration, aliquots were used for microscopy: (1) $50 \mathrm{ml}$ was fixed with acid Lugol's solution ( 1 to $2 \%$ ) for Utermöhl counts of ciliates (Rassoulzadegan \& Gostan 1976, Throndsen 1978), and (2) $10 \mathrm{ml}$ was fixed with borax-buffered formalin at $2 \%$ (v/v) final concentration (Steedman 1976) for epifluorescence counts of autotrophic pico- and nanoplankton (Hobbie et al. 1977, Davis \& Sieburth 1982). Cyanobacteria were counted during the whole period and plastidic pico- and nanoflagellates from November 1988 to December 1989. Samples used to assess the percentages of mixotrophic, strict heterotrophic and autotrophic ciliates were concentrated up to 500 -fold on a $10 \mu \mathrm{m}$ mesh net by a gentle reverse filtration technique (Sheldon \& Rassoulzadegan 1987). Concentrates were then fixed with borax-buffered formalin at $3 \%(\mathrm{v} / \mathrm{v})$ final concentration and settled in a $10 \mathrm{ml}$ Utermöhl chamber. To avoid pigment degradation, Utermöhl sedimentation took place in the dark and at $4{ }^{\circ} \mathrm{C}$. An average of 30 ciliates were examined under an epifluorescence microscope according to Rassoulzadegan et al. (1988), as modified by Bernard \& Rassoulzadegan (1990).

To compare the relative importance of the different organisms studied, numerical abundances were normalized into biovolumes. The volumes of the ciliates were 4000,21500 and $47000 \mu^{3}$ for cells $<30 \mu \mathrm{m}$ ('small cells'), cells ranging from 30 to $50 \mu \mathrm{m}$ ('medium cells') and cells $>50 \mu \mathrm{m}$ ('large cells') respectively (Rassouizadegan 1977,1982 ). Other volumes were: $0.32 \mu^{3}$ for cyanobacteria (size $\approx 0.84 \mu \mathrm{m}$ ESD), $1.77 \mu^{3}$ for plastidic picoflagellates (size $\approx 1.50 \mu \mathrm{m} \mathrm{ESD}$ ) and $65.45 \mu \mathrm{m}^{3}$ for plastidic nanoflagellates (size $\approx 5.00 \mu \mathrm{m} \mathrm{ESD}$ ).

The data on seasonal changes in light intensity were obtained from the 'Centre de la Météorologie Nationale', Nice, France.

\section{RESULTS}

\section{Biomass distribution}

Fig. 1 shows that mixotrophic and strict heterotrophic oligotrichs occurred year-round in surface waters at Point $\mathrm{B}$. Their respective biovolumes were of

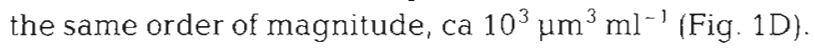
In general, blooms occurred in spring and autumn. The
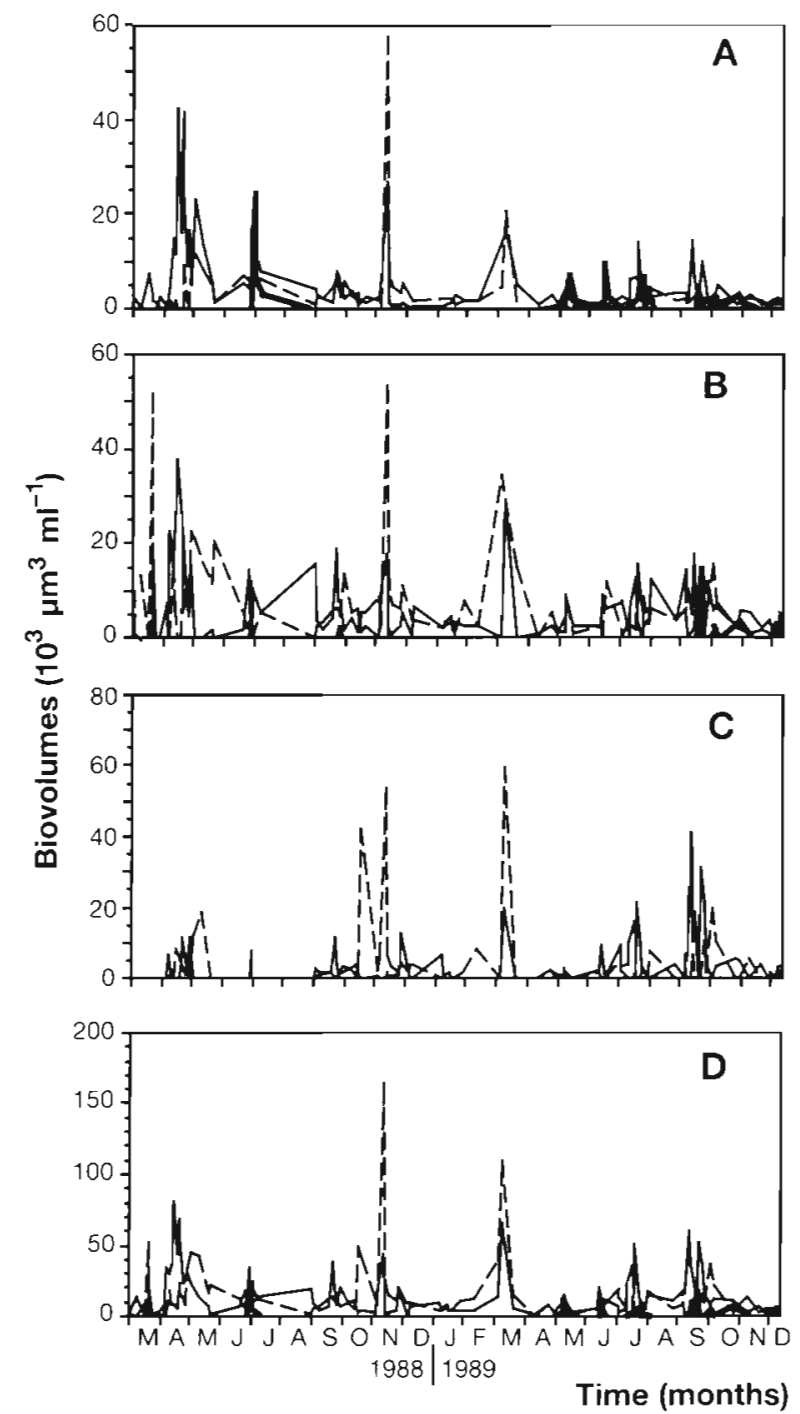

Fig. 1 Seasonal distribution of the biovolumes of oligotrichs (- strict heterotrophs, - - - mixotrophs) and of Mesodinium rubrum (-) at the surface of Point B from March 1988 to December 1989. (A) Ciliates $<30 \mu \mathrm{m}$, (B) ciliates 30 to $50 \mu \mathrm{m}$, (C) $>50 \mu \mathrm{m}$, (D) all sizes together

highest global (total of 3 size classes) values were in April $1988\left(80 \times 10^{3} \mu \mathrm{m}^{3} \mathrm{ml}^{-1}\right)$ for the mixotrophs and in November $1988\left(165 \times 10^{3} \mu^{3} \mathrm{ml}^{-1}\right)$ for the strict heterotrophs. The autotroph Mesodinium rubrum was observed only during a few months each year, with blooms occurring in summer (maximum of $25 \times 10^{3} \mu^{3}{ }^{3}$ $\mathrm{ml}^{-1}$ in July) (Fig. 1D).

With an annual average biovolume of $6 \times 10^{3}{\mu \mathrm{m}^{3}}^{3}$ $\mathrm{ml}^{-1}$, mixotrophs were dominated by medium-sized cells. They displayed spring blooms with biovolume maxima of $40 \times 10^{3} \mathrm{~mm}^{3} \mathrm{ml}^{-1}$ in April 1988 and $20 \times$ $10^{3} \mathrm{\mu m}^{3} \mathrm{ml}^{-1}$ in March 1989 for the small and mediumsized cells (Fig. 1A, B). These 2 groups also exhibited autumnal blooms with values reaching $30 \times 10^{3} \mu^{3}$ 
$\mathrm{ml}^{-1}$ in November 1988 and $15 \times 10^{3} \mu \mathrm{m}^{3} \mathrm{ml}^{-1}$ in September 1989 (Fig. 1A, B). Large mixotrophs were less present than the above groups. Their biovolume maxima reached values of $12 \times 10^{3} \mathrm{\mu m}^{3} \mathrm{ml}^{-1}$ in March,

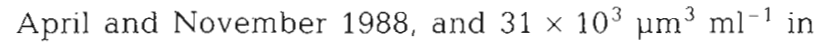
September 1989. For all the mixotrophs, secondary blooms were observed in July. All the blooms were synchronized in the 3 size categories. Minimal values were observed in winter (Fig. 1).

Strict heterotrophic ciliates also displayed spring and autumnal blooms with highest values observed in November $1988\left(58 \times 10^{3} \mu^{3} \mathrm{ml}^{-1}\right)$ and in March 1989

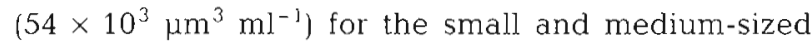
ciliates respectively (Fig, 1A, B). With an annual average of $4 \times 10^{3} \mathrm{\mu m}^{3} \mathrm{ml}^{-1}$, biovolumes of the large cell class were in general lower than those of the 2 other size classes (Fig. 1C).

Mesodinium rubrum was observed from April 1988 to December 1989. Only the small and medium-sized classes were represented. Maximal values of biovolumes for the small-sized cells were reached in summer: $25 \times 10^{3} \mathrm{\mu m}^{3} \mathrm{ml}^{-1}$ in early July 1988 and $10 \times$ $10^{3} \mathrm{\mu m}^{3} \mathrm{ml}^{-1}$ in mid-June 1989 (Fig. 1A). For mediumsized cells, the highest value was observed in September $1989\left(15 \times 10^{3} \mathrm{\mu m}^{3} \mathrm{ml}^{-1}\right)$ (Fig. 1B).

\section{Relative percentages of frequency}

Total mixotrophs comprised on average $51 \%$ of the total ciliate biovolume, but approached $100 \%$ especially in spring (Fig. 2D). Considered separately, the small, medium and large-sized mixotrophs represented 49,45 and $57 \%$ respectively of the total ciliate biovolume in their size category (Fig. 2A to $\mathrm{C}$ ). Large mixotrophs were absent for long periods in spring and summer 1988 but less frequently the rest of the year (Fig. 2C). With an annual average of $15 \%$ of the biovolume of small-sized ciliates, Mesodinium rubrum highest biovolume values were 53, 75 and $79 \%$ in July 1988, May 1988 and June 1989, respectively (Fig. 2A). The medium-sized cells were only represented in autumn (maximum of $74 \%$ in September 1989) (Fig. 2B).

\section{Occurrence of the main mixotrophic oligotrichous species}

Four genera were observed: Strombidium, Tontonia, Laboea and Lohmaniella. Strombidium was the only genus observed year-round and in all 3 size classes (Table 1). Small and medium-sized cells of Lohmaniella were observed but the medium-sized ones only sporadically. Three species of Tontonia were identified: T. appendiculariformis (only in 1989), T. gra-
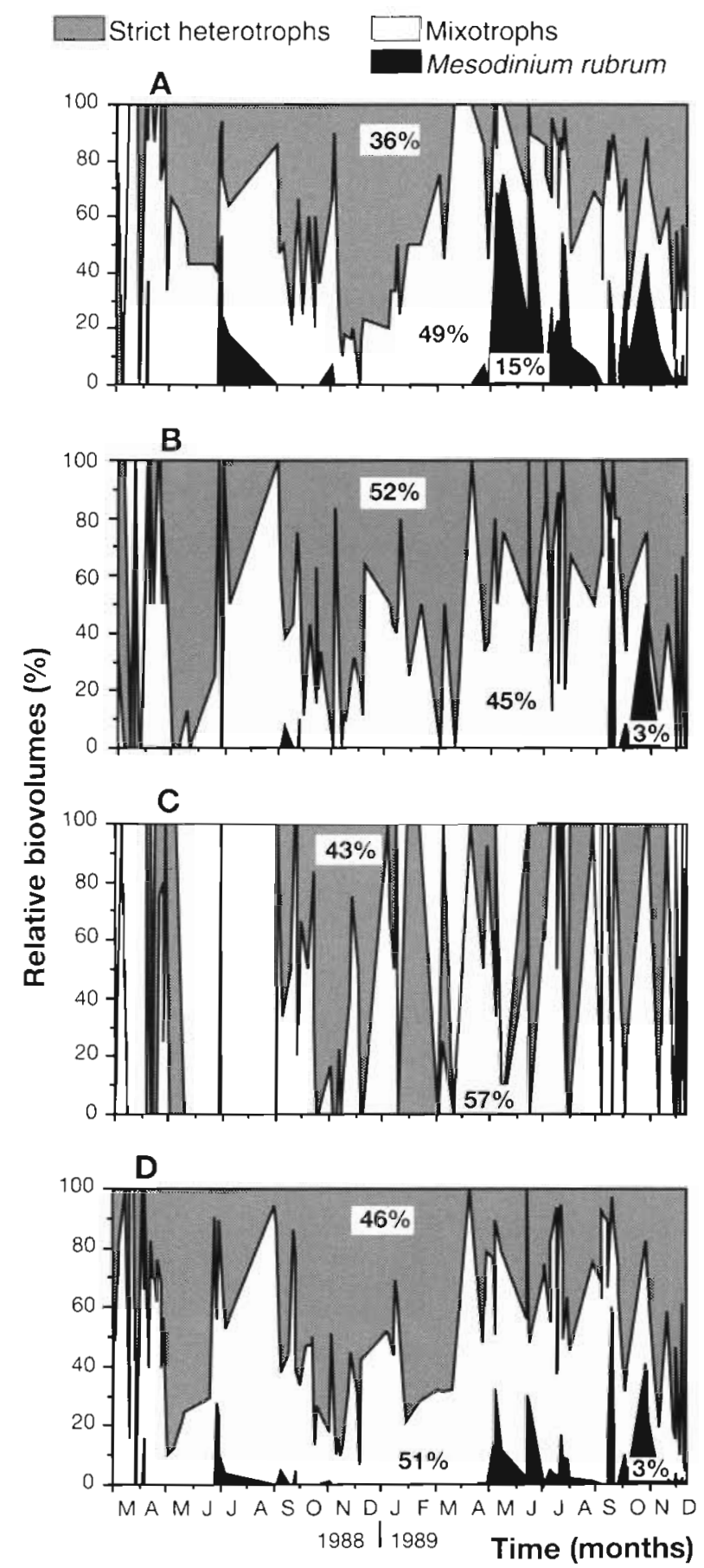

Fig. 2. Seasonal distribution of the relative biovolumes of oligotrichs (strict heterotrophs and mixotrophs) and of Mesodinium rubrum at the surface of Point B from March 1988 to December 1989. (A) Ciliates $<30 \mu \mathrm{m}$, (B) ciliates 30 to $50 \mu \mathrm{m}$, (C) $>50 \mu \mathrm{m}$, (D) all sizes together

cillima (except in spring) and T. ovalis (in summer and autumn 1989). Medium-sized cells of Laboea strobila were observed sporadically in autumn 1988 and in winter 1989; large-sized cells were only sampled in spring and autumn 1989. 
Table 1. Presence (+) or absence (-) of the different species of fluorescent ciliates (mixotrophic oligotrichs and Mesodinium rubrum) in different seasons at the surface of Point B from March 1988 to December 1989

\begin{tabular}{|c|c|c|c|c|c|}
\hline Species & $\begin{array}{c}\text { Size class } \\
(\mu \mathrm{m})\end{array}$ & Winter & Spring & Summer & Autumn \\
\hline \multicolumn{6}{|l|}{ Mixotrophs } \\
\hline \multirow{3}{*}{ Strombidium spp. } & $<30$ & + & + & + & + \\
\hline & $30-50$ & + & + & + & + \\
\hline & $>50$ & + & + & + & + \\
\hline \multirow[t]{2}{*}{ Lohmaniella sp. } & $<30$ & - & - & + & + \\
\hline & $30-50$ & - & + & - & - \\
\hline Tontonia & $30-50$ & - & - & + & - \\
\hline appendiculariformis & $>50$ & + & + & + & + \\
\hline \multirow{2}{*}{ Tontonia gracillima } & $30-50$ & + & - & + & + \\
\hline & $>50$ & + & - & + & + \\
\hline \multirow[t]{2}{*}{ Tontonia ovalis } & $<30$ & - & - & + & + \\
\hline & $30-50$ & - & - & + & + \\
\hline \multirow[t]{2}{*}{ Laboea strobila } & $30-50$ & + & - & - & + \\
\hline & $>50$ & + & + & - & + \\
\hline \multicolumn{6}{|l|}{ Autotroph } \\
\hline \multirow[t]{2}{*}{ Mesodinium rubrum } & $<30$ & - & + & + & + \\
\hline & $30-50$ & - & - & - & + \\
\hline
\end{tabular}

$\left(<20 \times 10^{3} \mu \mathrm{m}^{3} \mathrm{ml}^{-1}\right)$ developed in summer and autumn (Fig. 3A). Autotrophic picoflagellates bloomed twice: the main bloom in winter $\left(5 \times 10^{3} \mu^{3} \mathrm{ml}\right)$ and a

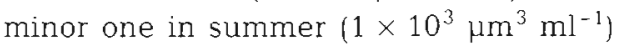
(Fig. 3B). The autotrophic nanoflagellates also displayed 2 blooms, in late winter $\left(17 \times 10^{4} \mu \mathrm{m}^{3} \mathrm{ml}^{-1}\right)$ and in summer $(19 \times$ $10^{4} \mu \mathrm{m}^{3} \mathrm{ml}^{-1}$ ) (Fig. 3C).

The average light intensity was $803 \mathrm{~J}$ $\mathrm{cm}^{-2}$, with minimal values in winter and maximal ones in spring and summer (1450 $\mathrm{J} \mathrm{cm}^{-2}$ ) (Fig. 4).

\section{DISCUSSION}

Marine oligotrichs and the haptorid Mesodinium rubrum generally dominate the populations of pelagic ciliates (Rassoulzadegan 1975, Smetacek 1981, Stoecker et al. 1987, 1989, Sherr et al. 1988, Nöthig \& von Bodungen 1989, Putt 1990b, Verity \& Vernet 1992). Except for a few cases (e.g. Stoecker et al. 1987, 1989, Putt 1990b,

\section{Other parameters}

The seasonal distribution of cyanobacteria was similar during the 2 years: maximal biovolumes in spring $\left(40 \times 10^{3} \mu \mathrm{m}^{3} \mathrm{ml}^{-1}\right.$ in 1988 and $33 \times 10^{3} \mu \mathrm{m}^{3} \mathrm{ml}^{-1}$ in 1989) and minimal ones in winter. Secondary blooms
Verity \& Vernet 1992), ecological studies do not generally take into account either the size or the trophic types of the oligotrichs, which may display both strict heterotrophy and mixotrophy (see Laval-Peuto 1992).

In this study, we use the term mixotrophy to mean a 'symbiosis' with plastid retention, implying the coexis-

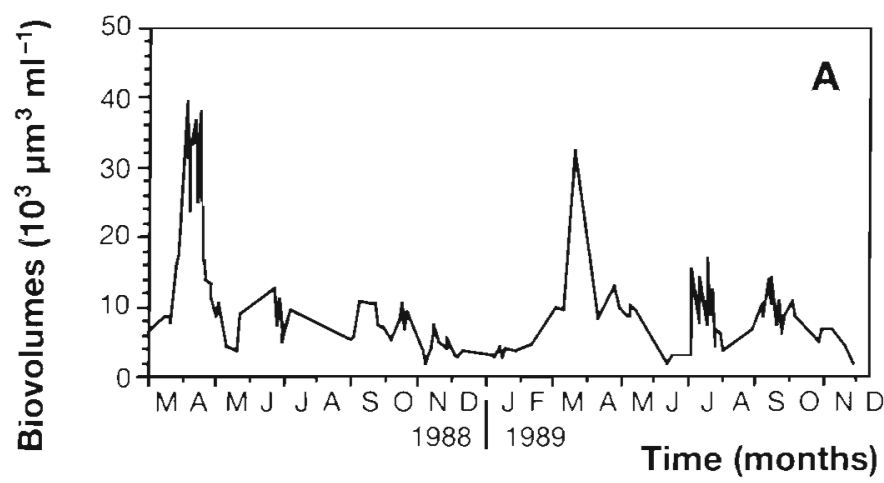

Fig. 3. Seasonal distribution of the biovolumes of (A) cyanobacteria and autotrophic (B) pico- and (C) nanoflagellates at the surface of Point B, from March 1988 to December for the cyanobacteria and from November 1988 to December 1989 for the flagellates
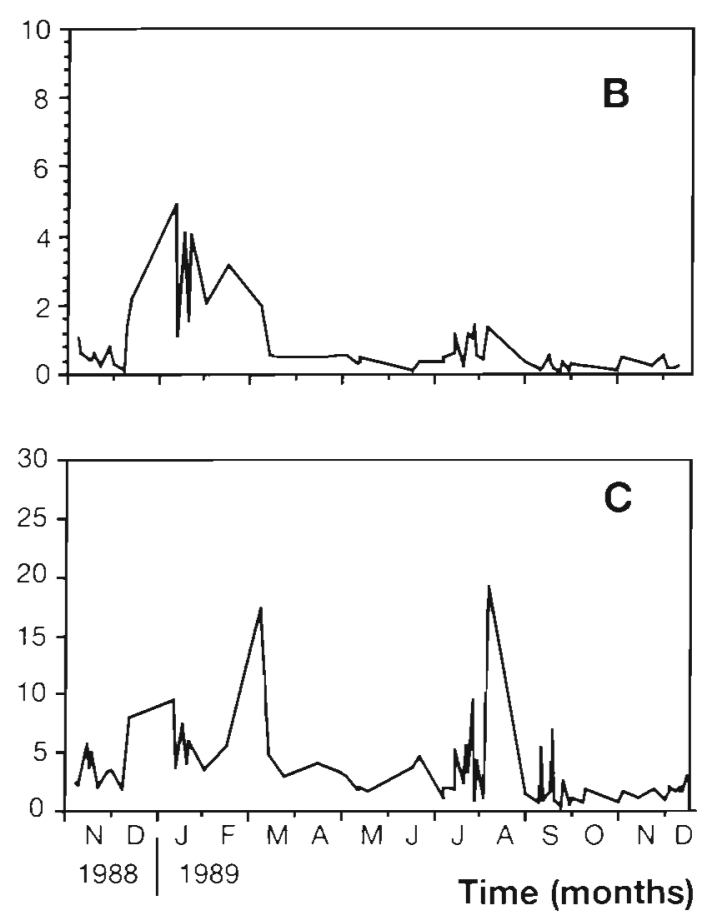


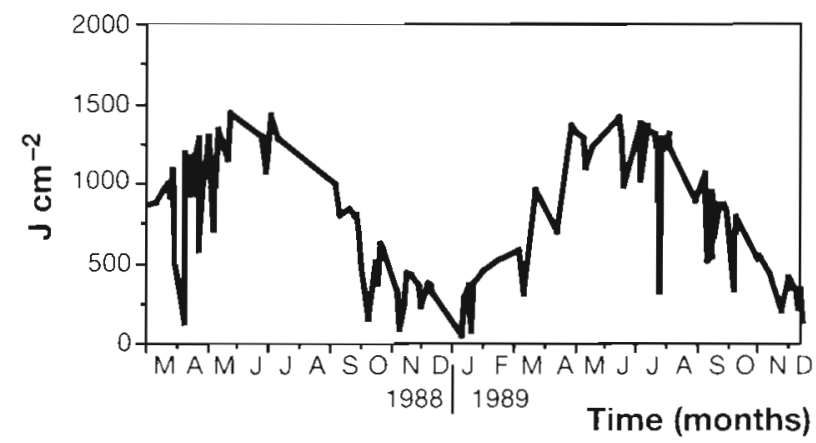

Fig. 4. Light intensity measured at the surface of Point B from March 1988 to December 1989

tence of heterotrophy and autotrophy (see Laval-Peuto 1992 and references therein). We consider that all the ciliates displaying a general fluorescence are mixotrophs, whatever the origin of the fluorescence (plastids or algae). No phagotrophic behaviour is known in Mesodinium rubrum (Lindholm et al. 1988) and we did not observe any prey in the cells during the $2 y \mathrm{r}$ of this study.

The 4 genera of oligotrichs reported in this study, Strombidium, Tontonia, Laboea and Lohmaniella (Table 1), include mixotrophic species (Laval-Peuto \& Rassoulzadegan 1988, Laval-Peuto 1992). Identification at the species level in Strombidium and Lohmaniella was uncertain with the investigating technique used here; thus we have assigned organisms to genera, only then taking their sizes into account (Table 1). Species were often found in 2 size classes, due to the variation in size of the cells throughout the cellular cycle. Laboea strobila is a widespread oligotrich (McManus \& Fuhrman 1986, Dale 1987, Stoecker et al. 1987, 1989, Gifford 1988, Laval-Peuto \& Rassoulzadegan 1988). While sporadically observed in autumn and in winter (LavalPeuto \& Rassoulzadegan 1988), in our study it was mostly present in spring 1989, but totally absent in summer. In the Atlantic Ocean, it has mostly been found in summer and in autumn (Blackbourn et al. 1973, McManus \& Fuhrman 1986), and in late spring in Norwegian fjords (Verity \& Vernet 1992). In the Mediterranean, its occurrence does not seem to be coupled with that of Mesodinium rubrum, (Table 1) as it is in the Atlantic (McManus \& Fuhrman 1986). The length of $M$. rubrum is reported as varying from 20 to $60 \mu \mathrm{m}$ (Lindholm \& Mork 1990). Only small and medium-sized cells were observed during our survey and they were sampled at different periods, exclusively in autumn for the medium-sized cells and from May to November for the small-sized ones (cf. McManus \& Fuhrman 1986, Dale 1987). Two varieties of $M$, rubrum, one small and one large, have also been observed in Southampton Water, UK (Leakey et al. 1993). M. rubrum could therefore be a complex of species.
Biovolumes of the mixotrophs and of the strict heterotrophs were of the same order of magnitude as those observed in the Atlantic Ocean, at least in summer (Stoecker et al. 1987). The domination of ciliate populations in the Mediterranean by medium-sized cells has been described earlier, but without taking into account the trophic type (Rassoulzadegan 1982). Average biovolume of the small-sized mixotrophs was almost equivalent to that of the medium-sized ones and average biovolume of the small-sized Mesodiniun rubrum was higher than that of the medium ones. This confirms the need to pay more attention to populations of small-sized ciliates in future studies (Sherr et al. 1986).

Mixotrophs constituted the greater part of the biovolume of all oligotrichs with $51 \%$ (Fig. 2D) but mostly of the large $(57 \%)$ and the small-sized $(49 \%)$ cells (Fig. 2C, B). If we add to the latter the $15 \%$ represented by the small-sized autotroph Mesodinium rubrum, then small-sized pigmented ciliates largely dominated their size class. Mixotrophs sometimes represented $100 \%$ of the total biovolume in spring and summer (Fig. 2). Stoecker et al. (1989) also observed in coastal areas in summer that more than $90 \%$ of the ciliates were mixotrophic. Low percentages of mixotrophic ciliates have been found in rich environments like Chesapeake Bay, USA (5\%; Dolan \& Coats 1990) or the Clyde Estuary, UK ( $<5 \%$; Laybourn-Parry et al. 1992). This might support the idea that mixotrophy is more emphasized in oligo- to meso-oligotrophic waters. Mixotrophs represented less than $10 \%$ of ciliates in late spring in Norwegian fjords (Verity \& Vernet 1992). Although in the minority in autumn and in winter, mixotrophs were never absent (Fig. 2). In Atlantic coastal waters, they constituted ca $10 \%$ of ciliates in the cold seasons (Stoecker et al. 1987).

There are no up-to-date studies on the role of light in the occurrence and the distribution of the different trophic types of ciliates. Indeed, in periods of high light intensities (Fig. 4), the percentage of mixotrophic ciliates and the diversity of species were higher (Fig. 2, Table 1). A positive correlation was found between the biovolumes of mixotrophs and light (Table 2). The biovolume of mixotrophic ciliates was also positively correlated to that of cyanobacteria (Table 2). This may be explained by the same light requirement in cyanobacteria (positive correlation between cyanobacteria and light; data not shown) and mixotrophic ciliates. In effect, phycoerythrin pigments are present both in cyanobacteria (White et al. 1977) and in some mixotrophs (cf. Laboea strobila; McManus \& Fuhrman 1986). It might well be that the relationship between mixotrophic ciliates and cyanobacteria is that of predator and prey, as is certainly the case for the relationship between strict heterotrophs and autotrophic nano- 
Table 2. Correlation coefficients of the positive relations found between the biovolumes of the different ciliates, light and the biovolumes of cyanobacteria and nanoflagellates $(n=110)$. Significant correlation coefficients are indicated in bold type

\begin{tabular}{|lccc|}
\hline & Strict heterotrophic oligotrichs & Mixotrophic oligotrichs & Mesodinium rubrum $<30 \mu \mathrm{m}$ \\
\hline Light & $0.02(\mathrm{p}=0.88)$ & $\mathbf{0 . 2 0}(\mathbf{p}=\mathbf{0 . 0 5})$ & $\mathbf{0 . 2 8}(\mathrm{p}=\mathbf{0 . 0 1})$ \\
Cyanobacteria & $0.02(p=0.87)$ & $\mathbf{0 . 4 4}(\mathbf{p}=\mathbf{0 . 0 1 )}$ & $0.04(\mathrm{p}=0.66)$ \\
Autotrophic nanoflagellates & $\mathbf{0 . 3 2 ( p = 0 . 0 1 )}$ & $0.06(p=0.64)$ & $0.10(p=0.69)$ \\
\hline
\end{tabular}

flagellates (Table 2). The present lack of correlation between the biovolume of flagellates and that of mixotrophic ciliates suggests that predation is not regular on this type of prey, which might be explained by the necessity of renewing the plastids only from time to time.

The physiological advantages of the symbiosis with plastids have been discussed elsewhere (Laval-Peuto \& Febvre 1986, Laval-Peuto 1992). These ciliates should have an advantage over the strict heterotrophic ones because they might modulate their source of carbon. Mixotrophic ciliates seem particularly well adapted to oligotrophic environments which are poor in nutrients and heterogeneous particles (Jonsson 1987 ) but with good light conditions, as in the Mediterranean. A better understanding of the energetic and material transfers through the mixotrophic ciliates would result in a better overview of the microbial food web.

Acknowledgements. Help and comments from Michele LavalPeuto are warmly acknowledged. Special thanks to D. J. Patterson for pertinent remarks and linguistic improvements. As a part of C.B.'s Ph.D., this research was supported by grants from CNRS/INSU and UA 716.

\section{LITERATURE CITED}

Auf dem Venne, H. (1990). Distribution of auto-, mixo-, and heterotrophic planktonic ciliates in the Greenland Sea in late spring and fall 1988. Comm. Meet. int. Coun. Explor Sea C.M.-ICES/L:10

Bernard, C., Rassoulzadegan, F. (1990). Bacteria or microflagellates as a major food source for marine ciliates: possible implications for the microzooplankton. Mar. Ecol. Prog. Ser. 64: 147-155

Blackbourn, D. J., Taylor, F. J. R., Blackbourn, J. (1973). Foreign organelle retention by ciliates. J. Protozool. 20: 286-288

Dale, T (1987). Diel vertical distribution of planktonic ciliates in Lindäspollene, Western Norway. Mar. microb. Food Webs 2: $15-28$

Davis, P. G., Sieburth, J. McN. (1982). Differentiation of phototrophic and heterotrophic nanoplankton populations in marine waters by epifluorescence microscopy. Annls Inst. océanogr. Paris 58: 249-260

Dolan, J. R. (1992). Mixotrophy in ciliates: a review of Chlorella symbiosis and chloroplast retention. Mar microb. Food. Webs 6: 115-132

Dolan, J. R., Coats, D. W. (1990). Seasonal abundances of planktonic ciliates and microflagellates in mesohaline
Chesapeake Bay waters. Estuar. coast. Shelf Sci. 31 $157-175$

Fenchel, T., Bernard, C. (1993a). A purple protist. Nature 362: 300

Fenchel, T., Bernard, C. (1993b). Endosymbiotic purple nonsulphur bacteria in an anaerobic ciliated protozoon. FEMS Microbiol. Lett. 110: 21-25

Gifford, D. J. (1988). Impact of grazing by microzooplankton in the Northwest Arm of Halifax Harbour, Nova Scotia. Mar. Ecol. Prog. Ser. 47: 247-258

Hobbie, J. E., Daley, R. J., Jasper, S. (1977). Use of Nuclepore filters for counting bacteria by fluorescence microscopy. Appl. environ. Microbiol. 33: 1225-1228

Jonsson, P. (1987). Photosynthetic assimilation of inorganic carbon in marine oligotrich ciliates (Ciliophora, Oligotrichina). Mar. microb. Food Webs 2: 55-68

Laval-Peuto, M. (1992). Plastidic protozoa. In: Reisser, W. (ed.) Algae and symbioses. Biopress Ltd, Bristol, p. 471-499

Laval-Peuto, M., Febvre, M. (1986). On plastid symbiosis in Tontonia appendiculariformis (Ciliophora, Oligotrichina). BioSystems 19: 137-158

Laval-Peuto, M., Heinbokel, J. F., Anderson, O. R., Rassoulzadegan, F., Sherr, B. F. (1986). Role of micro- and nanozooplankton in marine food webs. Insect Sci. Applic. 7: 387-395

Laval-Peuto, M., Rassoulzadegan, F. (1988). Autofluorescence of marine planktonic Oligotrichina and other ciliates. Hydrobiologia 159: 99-110

Laybourn-Parry, J., Rogerson, A., Crawford, D. W. (1992). Temporal patterns of protozooplankton abundance in the Clyde and Loch Striven. Estuar. coast. Shelf Sci. 35: 533-543

Leakey, R. J. G., Burkill, P. H., Sleigh, M. A. (1993). Planktonic ciliates in Southampton Water: quantitative taxonomic studies. J. mar. biol. Ass. U.K. 73: 579-594

Lindholm, T., Lindroos, P., Mörk, A.-C. (1988). Uitrastructure of the photosynthetic ciliate Mesodinium rubrum. BioSystems 21: 141-149

Lindholm, T., Mörk, A.-C. (1990). Depth maxima of Mesodinium rubrum (Lohmann) Hamburger \& Buddenbrock examples from a stratified Baltic Sea Inlet. Sarsia 75: $53-64$

McManus, G. B., Fuhrman, J. A. (1986). Photosynthetic pigment in the ciliate Laboea strobila from Long Island Sound, USA. J. Plankton Res. 8: 317-327

Nielsen, T. G., Kiørboe, T., Bjørmsen, P. K. (1990). Effects of a Chrysochromulina polylepis subsurface bloom on the planktonic community. Mar. Ecol. Prog. Ser. 62: 21-35

Nöthig, E.-M., von Bodungen, B. (1989). Occurrence and vertical flux of faecal pellets of probably protozoan origin in the southeastern Weddell Sea (Antarctica). Mar. Ecol. Prog. Ser. 56: 281-289

Putt, M. (1990a). Metabolism of photosynthate in the chloroplast-retaining ciliate Laboea strobila. Mar Ecol. Prog. Ser. 60: 271-282

Putt, M. (1990b). Abundance, chlorophyll content and photo- 
synthetic rates of ciliates in the Nordic Seas during summer. Deep Sea Res. 37.1713-1731

Rassoulzadegan, F. (1975). Ecologie et relations trophiques du microzooplancton dans un écosystème néritique. Thèse, Univ. P. et M. Curie, Paris

Rassoulzadegan, F. (1977). Evolution annuelle des cilies pélagiques en Méditerranée nord-occidentale, ciliés oligotriches 'non tintinnides' (Oligotrichina). Annls Inst. océanogr. Paris 53: 125-134

Rassoulzadegan, F. (1982). Le rôle fonctionnel du microzooplancton dans un écosystème méditerranéen. Thèse, Unıv. $P$. et M. Curie, Paris

Rassoulzadegan, F., Gostan, J. (1976). Répartition des ciliés pélagiques dans les eaux de Villefranche-sur-Mer. Remarques sur la dispersion du microzooplancton en mer et à l'intérieur des échantillons dénombrés par la méthode d'Utermöhl. Annls Inst. oceanogr. Paris 52: 175-188

Rassoulzadegan, F., Laval-Peuto, M., Sheldon, R. W. (1988). Partitioning of the food ration of marine ciliates between pico- and nanoplankton. Hydrobiologia 159: 75-88

Rogerson, A., Finlay, B. J., Berninger, U.-G. (1989). Sequestered chloroplasts in the freshwater ciliate Strombidium viride (Ciliophora: Oligotrichida). Trans. Am. Microsc. Soc. 108: $117-126$

Sanders, R. W. (1991). Mixotrophic protists in marine and freshwater ecosystems. J. Protozool. 38: 76-81

Sheldon, R. W., Rassoulzadegan, F. (1987). A method for measuring plankton production by particle counting. Mar microb. Food Webs 2: 29-44

Sherr, B. F., Sherr, E. B., Hopkinson, C. S. (1988). Trophic interactions within pelagic microbial communities: indications of feedback regulation of carbon flow. Hydrobiologia 159: $19-26$

Sherr, E. B., Sherr, B. F., Fallon, R. D., Newell, S. Y. (1986). Small aloricate cliates as a major component of the

This article was submitted to the editor marine heterotrophic nanoplancton. Limnol. Oceanogr 31. $177-183$

Smetacek, V.S. (1981). The annual cycle of protozooplankton in the Kiel Bight. Mar. Biol. 63: 1-11

Steedman, H. F. (1976). Zooplankton fixation and preservation. Monographs on oceanographic methodology. UNESCO, Paris

Stoecker, D. K. (1987). Photosynthesis found in some singlecell marine animals. Nature 326:49-53

Stoecker, D. K., Buck, K. R., Putt, M. (1992). Changes in the sea-ice brine community during the spring-summer transition, McMurdo Sound, Antarctica. I. Photosynthetic protists. Mar. Ecol. Prog. Ser. 84: 265-278

Stoecker, D. K., Michaels, A. E. (1991). Respiration, photosynthesis and carbon metabolism in planktonic ciliates. Mar. Biol. 108: 441-447

Stoecker, D. K., Michaels, A. E., Davis, L. H. (1.987). A large fraction of marine planktonic ciliates can contain functional chloroplasts. Nature 326: 790-792

Stoecker, D. K., Taniguchi, A., Michaels, A. E. (1989). Abundance of autotrophic, mixotrophic and heterotrophic planktonic ciliates in shelf and slope waters. Mar. Ecol. Prog. Ser. 50: 241-254

Throndsen, J. (1978). Preservation and storage. In: Sournia, A. (ed.) Phytoplankton manual. Monographs on oceanographic methodology. UNESCO, Paris

Verity, P. G., Vernet, M. (1992). Microzooplankton grazing, pigments, and composition of plankton communities during late spring in two Norwegian fjords. Sarsia 77 : $263-274$

White, A. W. Sheath, R. G., Hellebust, J. A. (1977). A red tide caused by the marine ciliate Mesodinium rubrum in Passamaquoddy Bay, including pigment and ultrastructure studies of the endosymbiont. J. Fish. Res. Bd Can. 34: $413-416$

Manuscript first received: December 15, 1993

Revised version accepted: March 22, 1994 